\title{
8
}

\section{Gostišče podjetne vaške skupnosti v Nadiških dolinah (Ažla, ı8. stoletje)}

\author{
Ines Beguš \\ Goriški muzej \\ Grajska cesta 1, 5000 Nova Gorica \\ ines.begus@goriskimuzej.si \\ Fakulteta za humanistične študije \\ Univerza na Primorskem \\ Titov $\operatorname{trg}$ 5, 6000 Koper \\ ines.begus@fhs.upr.si
}

\section{Uvod}

Nadiške doline so imele $\mathrm{v}$ času Beneške republike svojevrstno upravno in sodno ureditev ter posebne privilegije, ki so bili za gospodarstvo dolin izrednega pomena, saj so po svoji vsebini predvidevali med drugim tudi davčne olajšave.

Ti privilegiji so bili prebivalcem dolin podeljeni in tudi večkrat potrjeni s strani države iz dveh razlogov. Prvi razlog so bile meje $\mathrm{z}$ »Germanijo « (beri: slovenske habsburške dežele), kar je postala njihova obveznost in obenem dolžnost, $s$ katero so se izkazali v ključnih trenutkih, kot so bile vojne, bolezni in tihotapstvo. Drugi razlog sta bili "revščina« in "pomanjkanje«, ki sta bili povezani z nerodovitnostjo območij hribovitega sveta. Takšne razmere so bile sicer razširjene tudi drugje v hribovitem in alpskem svetu in tudi v neposredni soseščini Nadiških dolin, na primer na beneški strani v Karniji in na Tolminskem na habsburški strani meje. Zaradi tega je po eni strani verodostojno sklepati, da gre $\mathrm{v}$ tem primeru utemeljevanja podelitve privilegijev za retorični argument. Različni viri pa nam izkazujejo, da je navajanje »revščine« mogoče deloma tudi resnično.

$\mathrm{V}$ pričujočem prispevku bo najprej predstavljen ekonomski sistem Nadiških dolin, ki je primarno slonel na agrarnih panogah. Poleg teh so se kmetje posluževali tudi številnih neagrarnih dejavnosti, od katerih so prejemali dodatne vire dohodka. Kot lep primer posluževanja oz. integriranja kmetijskih in neagrarnih panog bo podrobno predstavljena zamisel o iz- 
vedbi izgradnje gostišča s strani izredno podjetne vaške skupnosti Ažla v 18. stoletju, ki je na ta način želela prodajati višek pridelave svojega vina ter oddajati gostišče $\mathrm{v}$ najem in tako pridobivati dodaten prihodek. V zaključku bo primer gostišča postavljen $\mathrm{v}$ kontekst integrirane kmečke ekonomije, ki po svoji definiciji izhaja iz predpostavke, da so kmetje posegali po neagrarnih virih dohodka ne le zaradi potrebe, ki je izvirala iz pomanjkanja virov za plačevanje dajatev, pač pa tudi zaradi priložnosti, ki so jim jih ponujale ekonomske dejavnosti, razvite v njihovem okolju. Na tej podlagi bomo poskušali ugotoviti, ali območje dolin lahko umestimo v ostala območja predalpskega prostora, ki so se na enak ali podoben način in s podobnimi razlogi posluževala kombiniranja agrarnih ter neagrarnih dejavnosti.

\section{Agrarno gospodarstvo Nadiških dolin in struktura posesti}

Gospodarstvo Nadiških dolin je deloma slonelo na različnih agrarnih dejavnostih. Na skoraj celotnem območju dolin so se prebivalci ukvarjali s poljedelstvom, za katerega sta bila značilna razmeroma skromen obseg in kmetijski prispevek. O tem nam pričajo nekatere navedbe čedajskih proveditorjev že iz 16. in 17. stoletja. Leta 1599 je proveditor Marcello za območje Nadiških dolin zapisal:

['Sklavonija'] skoraj v celoti leži v hribovitem in visoko goratem območju [...] in je zato nerodovitna za žita in vino, vendar obilna $z$ živalmi zaradi prostranih pašnikov in količine sena, ki se tam pobira, zživalmi in njihovimi pridelki, to so mlečni izdelki in sir, s katerimi se prehranjujejo ti prebivalci, kot tudi s kostanjem, lešniki in drugimi sadeži, ki jih je veliko skozi celotno leto (Tagliaferri 1976, 40).

Prebivalstvo v gorskem območju čedajskega teritorija po opisu Zorzija iz leta 1620 »nikoli ne vidi pšeničnega kruha in veliko mesecev v letu ostane tudi popolnoma brez drugih žit; $\mathrm{v}$ tem času se prehranjuje ne toliko $\mathrm{z}$ mlečnimi izdelki kot z zelišči in divjimi plodovi. Kljubuje vsakemu trpljenju in naporu in, ker se je prilagodilo naravi, glede na čas in neprilike uporablja tako meč kot plug « (Tagliaferri 1976, 102). Po besedah proveditorja Balbija iz leta $1637 \mathrm{v}$ »Sklavoniji« ni bilo rodovitnih njiv, ki bi lahko obrodile večje količine žita, so pa zato bolje »uspevali [...] vino, sadje, kozliči, les, seno, oglje, sir in mast, in sicer toliko, da so jih dobavljali celo v Palmo in v Videm « (Tagliaferri 1976, 106). 
Težke življenjske razmere in slabšo rodovitnost polj opisujejo tudi zapisniki v franciscejskem katastru z začetka 19. stoletja in potrjujejo, da je bilo stanje enako, kot ga opisujejo čedajski proveditorji dve stoletji poprej. Predvsem v višje ležečih območjih so naravni pogoji botrovali temu, da pridelek skoraj nobeno leto ni dozorel, tla pa so bila povečini ilovnata in kamnita, kar je oteževalo njihovo obdelovanje. V nižje ležečih predelih je bila klima sicer milejša, vendar so pridelek pogosto uničevali močni vetrovi in reke s svojimi hudourniškimi tokovi. Zemljo so morali »v hribovitem svetu še posebej, vendar tudi na splošno drugod, zaradi neugodne izpostavljenosti terena in mraza, sejati prekomerno « zato, da je bila zemlja spom-

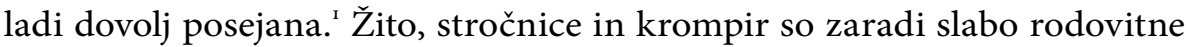
prsti sadili vsakoletno brez prahe. Žito so sejali spomladi in želi jeseni, le redko pa so se odločili za drugi posevek, saj običajno ni dozorel oz. sta ga uničila predčasna slana in mraz. ${ }^{2}$ Poleg poljedelstva je bila v Nadiških dolinah razširjena panoga živinoreja, ki je v višje ležečih območjih slonela na sistemu planšarstva. Na Matajurju in Miji so si prebivalci dolin uredili planine s krčenjem gozdnih površin, značilna pa je bila tudi paša živine na pašnikih, ki jih je pokrival gozd. Gozdovi so prebivalcem dolin nudili možnosti paše, les in dračje za kurjavo ter živalsko steljo, hrano v obliki gozdnih plodov ter surovino za izdelavo oglja. ${ }^{3}$

Iz tega lahko predpostavljamo, da predalpski svet, v katerega se uvrščajo Nadiške doline, ni nudil idealnih naravnih pogojev, ki bi kmetom zagotavljali kmetijski pridelek oz. ekonomsko samozadostnost skozi celo leto. Poleg tega je na obravnavanem območju zaznati istočasno izrazito drobitev hubnih zemljišč in večanje števila njihovih posestnikov. Kot tak primer lahko navedemo trinajst hub na območju Gorenjega Barnasa, ki jih je kot fevdalni gospod posedoval samostan Santa Maria in Valle. Ohranjeni dokumenti samostana nam omogočajo, da v kronološkem zaporedju od 14. do 18. stoletja sledimo razkrajanju hubnih enot in naraščanju števila (so)posestnikov ter deloma tudi vrstam in vrednostim dajatev. Hube so ime dobile po posestnikih, katerih potomci so skozi stoletja ohranjali hubno premoženje in stvarne pravice dednega zakupa. Prvi zapisi o posestnikih hub in dajatvah izvirajo iz leta 1375, pri njihovih navedbah pa je mogoče opaziti, da sta na nekaterih hubah že bila zapisana po dva posestnika, vendar so

ASV CA, AP, šk. 279, Drenchia, Nozioni agrarie di dettaglio.

Glej na primer ASV, CA, AP, šk. 279, Ponteacco, Nozioni agrarie di dettaglio.

ASU, ANA, šk. 4364, not. reg. št. 3, 275r-275v; šk. 4439, not. reg. B, 3455r-3455V; ASV, CA, AP, šk. 279, Costne con Topolo; Grimacco; Cravero, Nozioni agrarie di dettaglio idr. 
hube s prehodom na naslednjo generacijo ostale nedeljene. Sredi 16 . in v začetku 17. stoletja so se $\mathrm{v}$ zapisih poleg posestnikov pričeli pojavljati tudi soposestniki, ki so posedovali določen delež hube $\mathrm{v}$ zakupu in zanj plačevali dajatve. Zadnji popis vsake hube posebej iz leta 1764 izkazuje, da je eno hubo lahko obdelovalo tudi do 49 soposestnikov (tabela 8.1). ${ }^{4}$ Pri tem je sicer potrebno upoštevati sestavo hube glede na vrsto zemljišč (orna površina, travnik, gozd) in njihov obseg. Isti soposestnik je lahko imel svoja zemljišča tudi na več hubah. Takšno stanje v Gorenjem Barnasu nam torej izkazuje obsežno drobitev hubnih zemljišč najkasneje od 16. stoletja dalje ter izrazit porast števila njihovih obdelovalcev.

\section{Tabela 8.I: Velikosti hub in število soposestnikov v Gorenjem Barnasu leta I764}

\begin{tabular}{|c|c|c|c|c|c|c|}
\hline \multirow[t]{2}{*}{ Št. } & \multirow[t]{2}{*}{ Ime hube } & \multirow[t]{2}{*}{$\begin{array}{c}\text { Število } \\
\text { soposestnikov }\end{array}$} & \multicolumn{3}{|c|}{ Velikost cele hube } & \multirow[b]{2}{*}{ hektar } \\
\hline & & & čampi & quarti & tavole & \\
\hline 1 & Marino Blasin (Blažin) & 20 & 14 & 3 & 43 & 5,18 \\
\hline 2 & Urban Blasutigh (Blazutič) & 28 & 22 & 3 & 62 & 7,98 \\
\hline 3 & Simon Zurat & 3 & 8 & 3 & 49 & 3,07 \\
\hline 4 & Huba Mlasigh (Mlasič) & 13 & 13 & $\mathrm{O}$ & 209 & 4,58 \\
\hline 5 & Andrej Comino (Jakomin) & 28 & 23 & 2 & 112 & 8,25 \\
\hline 6 & Luka Zanutigh (Zanutič) & 19 & 33 & 0 & 116 & 11,58 \\
\hline 7 & Jernej Coceanigh (Kocjanič) & 31 & 25 & 2 & 36 & 8,94 \\
\hline 8 & Kristjan Zuanigh (Zuanič) & 39 & 37 & 2 & 12 & 13,15 \\
\hline 9 & Marino Coren (Koren) & 10 & 28 & 1 & 92 & 9,91 \\
\hline 10 & Luka Zilii (Zili) & 24 & 28 & 2 & 11 & 9,99 \\
\hline 11 & Matija Petricigh (Petričič) & 33 & 48 & 2 & 60 & 17,01 \\
\hline 12 & $\begin{array}{l}\text { Huba Blasiutigh, Colau, Muri- } \\
\text { ach(Blazutič, Kolau, Muriak) }\end{array}$ & 49 & 67 & 1 & 164 & 23,59 \\
\hline \multirow[t]{3}{*}{13} & Leonard Coren (Koren) & 9 & 6 & 3 & 186 & 2,39 \\
\hline & Skupaj & & & & & 125,63 \\
\hline & $\begin{array}{l}\text { Število posameznih soposest- } \\
\text { nikov } 5\end{array}$ & 94 & & & & \\
\hline
\end{tabular}

Vir: ASU, CRS, šk. 147, Stima, e Ratte ...; Beguš 2015, 130.

Podobno strukturo posesti in njene delitve, kot je bila prikazana na primeru Gorenjega Barnasa, zasledimo tudi drugod na furlanskem in

4 Dve hubi predstavljata izjemo, in sicer huba Blazutič, Kolau, Muriak, kjer so se tri hube združile v eno, ter huba Simona Zurata, ki se je razdelila na dva deleža in na kateri od 17. stoletja dalje poleg dednega zakupa zasledimo tudi kratkoročni zakup.

5 Nekateri soposestniki so imeli zemljišča na več hubah, vseh posameznih soposestnikov je torej bilo 94 . 
goriškem območju na habsburški strani. Kot pojasnjuje Bianco, je bila v Furlaniji do 17. stoletja dajatev določena izvornemu posestniku in nato njegovim dedičem. Sčasoma pa je možnost kmeta, »da prosto preda zemljišča svojim dedičem, jih proda, zamenja ali najame kredit, za katerega jamči s posedovanimi zemljišči, povzročila njihovo postopno delitev in drobitev hub in pravdnih dajatev, dokler ni postalo stanje tako zapleteno in prepleteno, da je že močno oteževalo izterjavo dajatev« (Bianco 2012, 215). Na območju večjih zemljiških gospostev v zahodni Sloveniji je postala delitev hub izrazita v 16. stoletju. Kot ugotavljata Vilfan in zatem Panjek, ${ }^{6}$ je tudi tu kmet zemljo dojemal kot svojo in jo prodajal, oddajal in z njo trgoval, četudi jo je posedoval $\mathrm{v}$ obliki zakupa in ne na podlagi zakupnega prava. Na to kaže dejstvo, da je eno hubo naseljevalo več družin, kot se je tega zemljiško gospostvo zavedalo. Tako je na Krasu eno hubo obdelovalo štiri, pet ali več družin, na Tolminskem pa je v 18. stoletju huba štela do osemnajst soposestnikov. Istočasno je bilo na omenjenih območjih mogoče zaznati naraščanje števila prebivalcev $\mathrm{z}$ malo ali nič zemlje, kot so kajžarji in gostači. Velikost kmetij je bila zelo majhna in je le redko dosegla 5 ha, $\mathrm{z}$ izjemo kmetij v alpskih območjih, kjer so obsegale tudi prostrane pašnike. Ob upoštevanju pogojev, ki jih je nudila kraška zemlja, in pomanjkanju obdelovalnih površin v alpskem svetu je Panjek za to območje prišel do sklepa, da večina kmečkega prebivalstva ni živela samo od kmetijstva in da za marsikoga kmetijstvo niti ni nujno predstavljalo osrednjega vira preživetja (Panjek 2011, 305; 2015, 192). Taka interpretacija ima oporo tudi v delih drugih slovenskih zgodovinarjev.

Podobno lahko predvidevamo tudi za Nadiške doline. Kot kaže primer hub v Gorenjem Barnasu, kmetije glede na svojo majhnost in razdrobljenost obdelovalnih površin niso mogle zagotavljati prehrambne samozadostnosti svojih obdelovalcev, pa čeprav je isti kmet posedoval več deležev različnih kmetij. Če pri tem upoštevamo še neugodne naravne pogoje predalpskega sveta, lahko predpostavljamo, da kmetje v Nadiških dolinah niso živeli izključno od kmetijstva.

Poglejmo še dajatve, ki so jih posestniki oz. posamezne hube plačevale samostanu. Samostan je fiksne dajatve določil že v 14. stoletju, plačevali pa so jih v naravi in denarju na podlagi dednega zakupa. Skozi čas sta se vrsta in količina dajatev polagoma spreminjali. V 18. stoletju, ko je torej posamezno hubo obdelovalo več soposestnikov, so dajatve vsakega posameznika predstavljale delež od skupnih, fiksnih dajatev celotne hube.

6 Panjek 2017a; 2017b s tam navedeno slovensko literaturo. 
Preferenčni prejemek samostana v naravi je ves čas predstavljala pšenica, poleg nje pa se najpogosteje pojavljajo še kokoši, piščanci, kozlički in jajca. Leta 1764 je tako pšenica skupaj z ostalimi dajatvami v naravi predstavljala $\mathrm{v}$ povprečju približno $80 \%$ denarne vrednosti celotne fevdalne rente vseh trinajstih hub, preostalih $20 \%$ pa so predstavljale denarne dajatve.

V slovenskem zgodovinopisju je obseg denarnih dajatev razumljen kot pokazatelj vključevanja kmečkega prebivalstva $v$ tržne dejavnosti. Plačevanje rente $v$ denarju je bilo posledica teženj zemljiških gospodov po pretvarjanju naravnih dajatev $\mathrm{v}$ denarne. Ta pojav je obravnavan $\mathrm{v}$ sklopu procesa komercializacije zemljiškega gospostva, v okviru katerega so težnje zemljiških gospodov po plačevanju dajatev $\mathrm{v}$ denarju kmete »silile« v vključevanje v trgovske posle (Gestrin 1973, 73-4). V Furlaniji je bila sicer stvarnost nekoliko drugačna kot $\mathrm{v}$ slovenskem prostoru, tu so se zemljiški gospodje usmerjali $\mathrm{v}$ pridelavo bolj tržnih pridelkov na svojih gospostvih. To so dosegli s spreminjanjem zakupnih razmerij iz dolgoročnih zajmov, ki so predvidevali nespremenljivost zakupnin in ovirali povečevanje rente, $\mathrm{v}$ kratkoročne pogodbe, ki so omogočale spreminjanje dajatev ter večjo agrarno donosnost (Bianco 2011). Kljub temu pa lahko tudi za Nadiške doline sklepamo, da je tamkajšnje kmečko prebivalstvo denarna sredstva za poplačilo fevdalne rente $\mathrm{v}$ denarju pridobivalo iz neagrarnih virov dohodka.

Poglejmo si v nadaljevanju, katerih neagrarnih dejavnosti so se kmetje v Nadiških dolinah posluževali in zakaj.

\section{Neagrarne dejavnosti v Nadiških dolinah}

Posebej zanimiv in poveden vir o neagrarnih dejavnostih v Nadiških dolinah je zemljevid iz leta 1751 avtorja Janeza Batista Damianija. Ta upodablja vasi landarske in merške doline ter »skupnosti« Dreka, ki je imela $\mathrm{z}$ vidika sodne ureditve poseben status. ${ }^{7}$ Poleg naselij so posebej označene še reke, objekti in prelaz Podobnesec. Pod izrisom dolin so naštete izrisane vasi, število hiš v vaseh ter kratki zapisi o ekonomskih dejavnosti, ki so se tam izvajale (tabela 8.2). Predvidevamo lahko, da je avtor zemljevida vsaki vasi pripisal najznačilnejšo gospodarsko panogo, s katero se je ukvarjala večina njenih prebivalcev. To pomeni, da navedene dejavnosti niso bile nujno izključne in edine dejavnosti, s katerimi so se prebivalci vasi preživljali, so pa bile prevladujoče oz. glavne. 
Iz zapisov panog je razvidno, da so se $\mathrm{v}$ nižinskih kot tudi pobočnih predelih prebivalci ukvarjali večinoma s poljedelstvom in/ali z živinorejo. Na teh območjih so zemljišča označena kot »odlična« ali »dobra« za pridelovanje žita in vina. V vaseh oz. skupnostih Polava in Dreka so se prebivalci ukvarjali tudi s pridelavo sadja. Na teh območjih je torej prevladovala agrarna dejavnost. $\mathrm{V}$ krajih $\mathrm{v}$ bližini regionalne ceste ter $\mathrm{v}$ hribovitih in obmejnih območjih so se po zapisih na zemljevidu prebivalci ukvarjali s kmetijstvom, z neagrarnimi dejavnostmi in živinorejo. Najpogosteje se omenja trgovina $\mathrm{z}$ živino in lesom, ki so ga prodajali v Videm. V vaseh Perati, Trčmun in Gorenji Barnas je bila razširjena prodaja sira, v Trčmunu je posebej zapisana še izdelava masti. Trgovsko dejavnost je omogočala cestna povezava skozi Nadiške doline od Čedada do Kobarida in dalje proti Bovcu oz. proti furlanski nižini, po kateri je potekala tudi trgovina na daljše razdalje. $\mathrm{V}$ vaseh $\mathrm{v}$ najvišje ležečih predelih, kjer glede na rabo tal in nadmorsko višino poljedelstvo ni dobro uspevalo, je med agrarnimi dejavnostmi prevladovala živinoreja, na zemljevidu pa sta med neagrarnimi dejavnostmi največkrat omenjeni predvsem trgovina in obrtna dejavnost, vezani pretežno na les. $V$ vasi Ložec so se na primer vaščani ukvarjali s trgovino in si "prizadevali z izdelovanjem lopat, pezenalov (mernikov) itd. in drugih lesenih orodij«, v Matajurju so prav tako izdelovali orodje iz lesa, $v$ Gorenjem in Dolenjem Mersinu pa so se ukvarjali z drvarjenjem in lesarstvom.

Zemljevid tako obenem slikovito in shematično prikazuje osnovne poteze kmečke ekonomije v Nadiških dolinah sredi 18. stoletja. Povedni pa so tudi drugi viri, nastali sicer $\mathrm{v}$ začetku 19. stoletja, iz katerih lahko identificiramo tiste vrste neagrarnih dejavnosti, za katere sklepamo, da so se razvile vsaj že v stoletju poprej. Tako na primer videmski geodet in javni izvedenec Rota leta 1807 na območju dolin, ki so bile takrat del Italijanskega kraljestva, omenja »odlične pašnike «, na katerih se pasejo voli, koze in ovce, od katerih pridobivajo mleko za izdelovanje »dobrih sirov« in volne. Poleg kvalitetnih pašnikov je tu zemlja dajala tudi »okusno sadje«, kot so ribez, maline in jagode, ki je drugod zaželeno na "razkošnih mizah bogatašev«, $\mathrm{v}$ dolinah pa so se $\mathrm{z}$ njim pasle koze. $\mathrm{Z}$ omenjenim sadjem so po njegovih pričevanjih veliko trgovali vse do Trsta. Poleg žita in sadja Rota omenja še pridelavo »odličnega vina, imenovanega rebula«, seno, »izdelke živalskega izvora, lesarstvo in oglarstvo «, ki so prebivalcem zagotavljali preživetje (Bianco 2003a, 124-5). Tu je potrebno opozoriti, da interpretacije v zapisu Rote niso skladne $\mathrm{z}$ interpretacijami $\mathrm{v}$ franciscejskem katastru oz. statistič- 


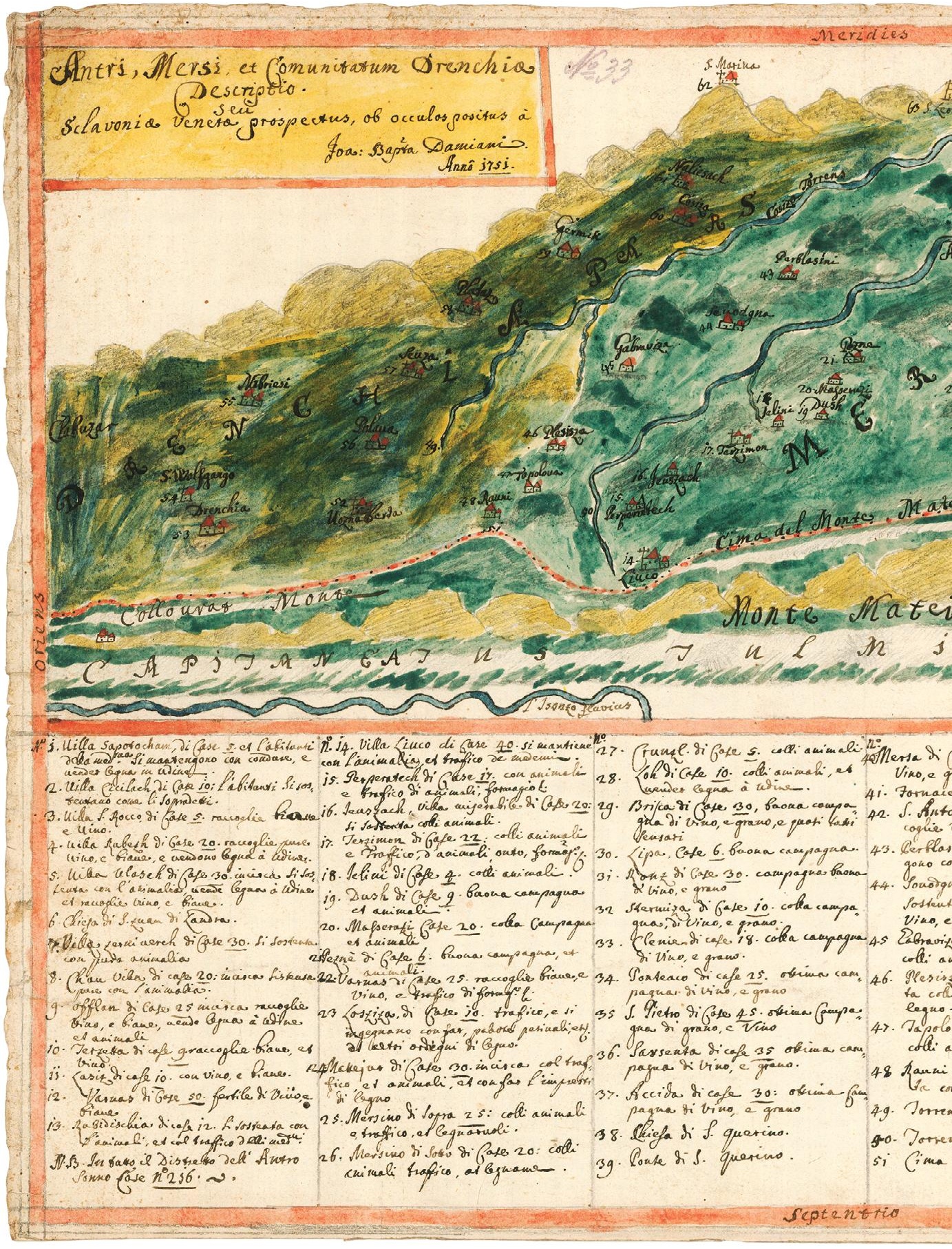




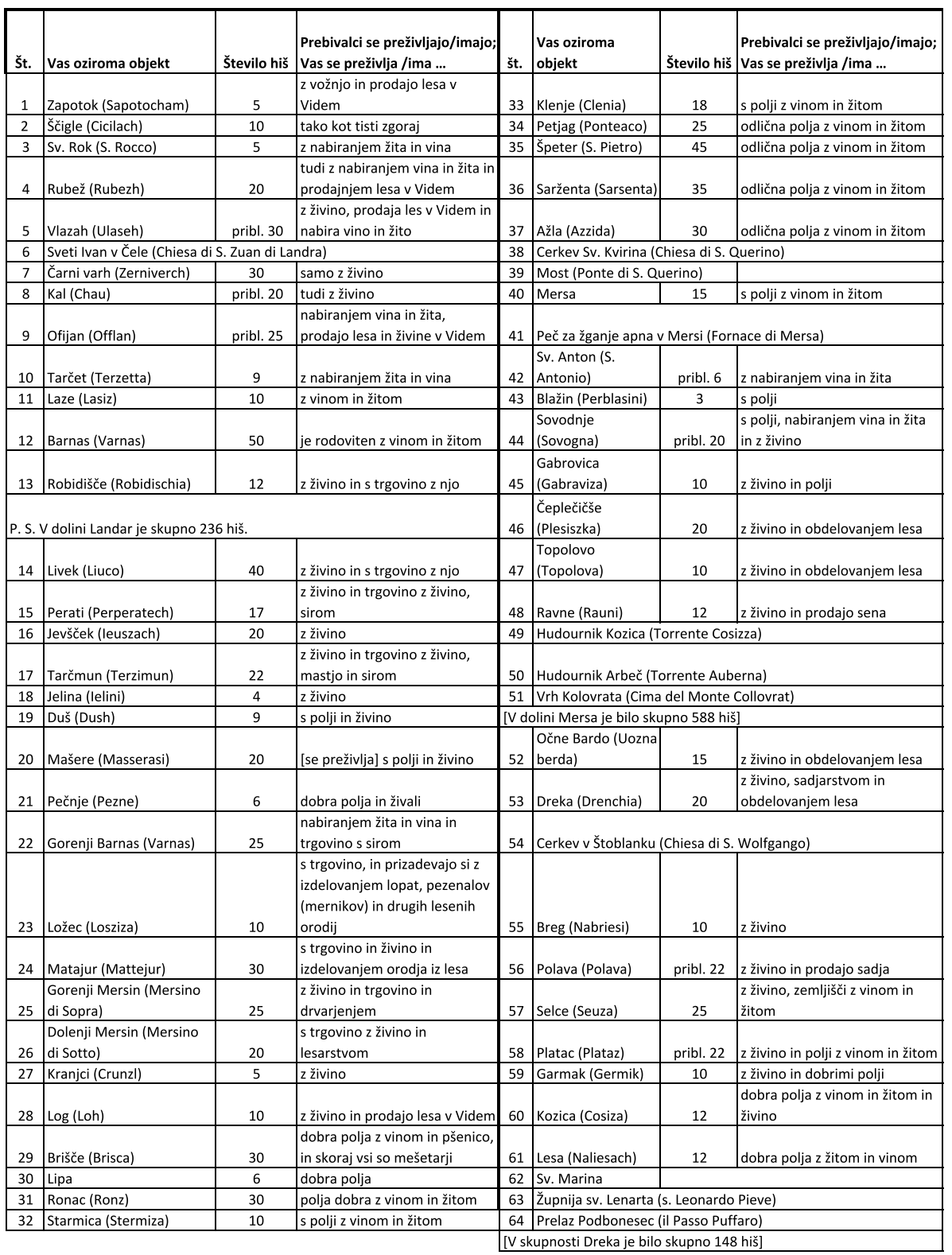

Tabela 8.2: Popis ekonomskih dejavnosti po posameznih vaseh v Nadiških dolinah na podlagi zemljevida iz leta i75ı. 
nem popisu iz istega leta. Slednji na primer za večino takratnih občin navaja, da primanjkuje določenih žitaric in živine oz. kmetijstvo ni zadostno (Corbellini, Cerno in Sava 1992, 560-81). Tako lahko razlike v razlagah pripišemo različnim merilom med opazovalci oz. pisci zapisov.

Poleg naštetih neagrarnih dejavnosti je obstajalo tudi mezdno delo, o katerem sicer zanesljivo lahko trdimo šele na podlagi pričevanj iz 19. stoletja. Rota omenja, da so se le-tega poleg moških posluževale tudi ženske kot dninarke ali v obliki dela na domu premožnih. A tudi moški niso bili "povsem brez izseljenskega duha«, saj so se ukvarjali »z drobno trgovino lesenih gospodinjskih pripomočkov iz lastne obrti«, ki so jih izdelovali »za uporabo v kuhinjah revnih ljudi« (Bianco 2003a, 124-5). Tudi zapisi v franciscejskem katastru omenjajo mezdno delo, v okviru katerega so kmetje spomladi in poleti za pomoč na polju najemali dninarje. Kataster omenja tudi tekstilno proizvodnjo v občini Dreka, kjer so ženske delale predvsem »kot šivilje, da so lahko nahranile otroke. $\mathrm{Z}$ materialom, lanom, konopljo in izdelki za prodajo so zalagale trgovce v Čedadu «. ${ }^{8} \mathrm{Kmetje}$ so pridelke in izdelke prodajali na lokalnih trgih v Svetem Lenartu, Čedadu, Vidmu ter v nekaterih obmejnih slovenskih deželah. ${ }^{9}$ Po načelu izmenjave so iz nižinskih predelov Furlanije dobavljali predvsem koruzo, tam pa prodajali oz. izmenjevali svoje izdelke. Na trg se je kmet vključeval tudi z morebitnimi presežki kmetijske proizvodnje.

Kot je mogoče razbrati iz virov, so pomemben delež neagrarnega dohodka prinašali gozdovi oz. les. Gozdovi sicer zaradi težje dostopnosti, neustrezne infrastrukture in oddaljenosti niso bili primerni za intenzivnejše izkoriščanje. To so ugotavljali že izdelovalci katastra za hrastove gozdove leta 1744, ki ga je beneška država izdelala za potrebe vojaške mornarice. Zapisali so, da zaradi težje dostopnosti in neugodnih razmer hrastova drevesa niso zrasla do višine, ki je bila zakonsko predvidena za potrebe beneškega ladjevja ${ }^{10}$ Enako so beležili izdelovalci franciscejskega katastra v začetku 19. stoletja za vse gozdove v Nadiških dolinah. Kljub temu so kmetu nudili listje, dračje in male veje za živalsko steljo ter gnoj, prostor za pašne površine, prehrano $\mathrm{v}$ obliki gozdnih plodov ter surovino za gradnjo in izdelavo oglja. Med gozdnimi sadeži velja poleg že naštetih jagod, malin in borovnic omeniti še lešnike in kostanje. Kostanjeva drevesa so porašča-

8 ASV, CA, AP, šk. 279, Drenchia, Nozioni generali territoriali.

9 ASV, CA, AP, šk. 280, Tarcetta, Nozioni generali territoriali.

10 ASV, PsB, registro no. 161. 
la skoraj večji del Nadiških dolin, les in plodove pa so prodajali na bližnjih trgih Čedada in Vidma. ${ }^{\text {II }}$

Planšarstvo in obdelava pašnikov sta bila poleg živinoreje ključna za pridelavo živalskih izdelkov (maslo) in sena, precej razširjena na območju dolin pa je bila tudi trgovina $\mathrm{z}$ živino. To nam potrjujejo že obravnavan zemljevid iz leta 1751 pa tudi poročila o izbruhu goveje epidemije, ki je prizadela Nadiške doline sredi 18 . stoletja. Širjenje bolezni je čedajski proveditor skušal omejiti z začasno zaporo trgovine $\mathrm{z}$ živino med Vidmom in dolinami, kot pojasnilo pa je navedel, da je bila "Sklavonija« ob začet$\mathrm{ku}$ epidemije »tako bogata $\mathrm{z}$ govedom, da bi bilo mogoče samo iz teh krajev pridobiti in nadomestiti izgube na deželni ravni, (ki so nastale zaradi pomanjkanja goveda) «. ${ }^{12} \mathrm{O}$ tranzitni trgovini z živino skozi Nadiške doline nam priča tudi mitninska knjiga postaje na Podbonescu, v kateri je zapisano, da je v obdobju od avgusta 1755 do julija 1756 čez mitnico šlo 567 glav goveda (Tagliaferri 1989, 62). Nadiške doline so se torej vključevale v mednarodno, to je habsburško-beneško trgovino $\mathrm{z}$ živino.

Trgovina je v večji meri potekala po cesti skozi doline, ki je povezovala Čedad in Videm s Koroško preko Kobarida, Bovca, Predela, Trbiža in Beljaka. S Kranjsko se je povezovala preko Škofje Loke in Tolmina mimo mitninske postaje v Bači (Šumrada 1987, 313; Blaznik 1973, 224). S prehodom zgornjega Posočja pod habsburške dežele v prvi avstrijsko-beneški vojni je Čedad izgubil pravico do uveljavljanja poti po t. i. 'bovški cesti'. S tem so v 16. stoletju začele slabeti trgovske povezave med Koroško in Čedadom, poleg tega so beneške oblasti prepovedale trgovino skozi Nadiške doline, $\mathrm{s}$ čimer naj bi omejile tihotapstvo. Čedadu so omejen promet z železom s Koroške dovolile toliko, kolikor ga je potreboval za svoje potrebe. Na drugi strani vzpostavljene meje so Habsburžani zgradili 'soško pot', ki je peljala iz Gorice čez Solkan, Kanal in Volče do Kobarida, kjer se je cesta združila s cesto iz Nadiških dolin in nato vodila proti Bovcu. $\mathrm{Na}$ ta način se je blago, med katerim se omenjajo železnina, tkanine, usnje, žito, svinec idr., iz bližnjih habsburških dežel izognilo mitnici v Nadiških dolinah ter potovalo neposredno proti Gorici in habsburškemu pristanišču Štivanu pri Devinu (Tagliaferri 1976, XLV, XLVII-XLIX: Gestrin 1991, 112).

Z izgradnjo soške ceste so torej Čedad in Nadiške doline občutili velik padec trgovine in prometa po cesti skozi Podbonesec. Na to so večkrat opo-

11 ASV, PsF, šk. 322, 3; ASV, CA, AP, šk. 279, S. Pietro, Nozioni generali territoriali; Cravero, Nozioni generali territoriali.

12 ASV, PaS, šk. 476, dok. dat. 10. september 1747. 
zorili čedajski proveditorji, ki so $\mathrm{v}$ svojih poročilih pisali o močnem upadu davka na izvoženo vino, ki ga je zaračunavala mitnica na Podbonesecu, ter soglasno zatrjevali, da je bilo zaprtje ceste zaradi strahu pred tihotapstvom zelo neugodno za mestno in državno blagajno, negativno pa je vplivalo tudi na lokalno trgovino (Tagliaferri 1976, 15, 38, 94). Proveditor Pisani pa $\mathrm{v}$ svojem poročilu omenja še eno neagrarno dejavnost, s katero so se kmetje ukvarjali pred omejitvijo trgovine, to je tovorništvo. Kot pravi, so kmetje »zdaj najrevnejši izmed vseh v deželi Furlaniji, saj so [doslej] pomagali prevažati trgovsko blago s svojimi vozovi in z živalmi ter s prodajo svojega sena in na druge načine izdatno prispevali k zadovoljevanju svojih potreb « (Tagliaferri 1976, 82). Kot kaže, je preusmeritev trgovine na druge prometne povezave vplivala na upad tudi te dejavnosti.

Omenjeno tihotapstvo ter druge nezakonite oblike trgovine so bili $\mathrm{v}$ hribovitih predelih vzhodnega predalpskega prostora sestavni del trgovine in prometa. Na habsburški strani je bilo precej razširjeno tihotapljenje živine in blaga (Žontar 1956-57, 85; Verbič 1974, 14-5; Panjek 2002, 221), v vzhodni Furlaniji pa sta bila v 18. stoletju med donosnimi nelegalnimi dejavnostmi razvita tihotapstvo s soljo ter pridelava in prodaja tobaka, razširjeno pa je bilo tudi tihotapstvo z živino, oljem in žiti (Gestrin 1991; Bianco 1990; 1998; Castellarin 2001). V Nadiških dolinah lahko na podlagi arhivskih virov potrdimo tihotapljenje mesa in kož ter tobaka, ${ }^{13}$ glede na to, da je šlo za (pol)prikrito obliko trgovanja, pa lahko sklepamo, da so kmetje kupčevali tudi z drugimi tržno zanimivimi izdelki, ki so jim prinašali dodaten vir dohodka. Primer tihotapljenja mesa in kože zasledimo v času goveje epidemije in poostritve trgovine $\mathrm{z}$ živino, ko so državne oblasti ugotovile, da "preveč zlahka lahko slaba nrav nekoga privede do tega, da izkoplje meso, ki je zakopano na poljih, ne preveč oddaljenih, saj se je na žalost tako hud prenos [bolezni?] zgodil tudi zaradi zaslužka s kožami«. V izogib temu je čedajski proveditor objavil odlok, v katerem je dovolil prodajo mesa izključno tistim mesarjem $\mathrm{v}$ mestu Čedad in na njegovem teritoriju, ki so prestali predvidene kontrole, ti pa so smeli prodajati meso samo v svojih mesnicah. ${ }^{14}$ Tudi dobiček od tobaka je bil manjšim tihotapcem pomemben vir dohodka, $v$ gorskem svetu pa so takšno tihotapstvo tiho dopuščale tudi vaške skupnosti. Čeprav so lokalne in državne oblasti izvajale stroge

13 ASV, Inquisitori di stato, šk. 38, Lettere ai rettori ..., 6. oktober 1795; ASV, PaS, šk. 476, dok. dat. 3. september 1747.

14 ASV, PaS, šk. 476, dok. dat. 3. september 1747. 
ukrepe proti ilegalni trgovini s tobakom, so včasih morale priznati nemoč v boju zoper tihotapskim skupinam (Bianco 1990, 101, 105).

Še ena neagrarna dejavnost, ki so se je nadiški kmetje posluževali v sklopu trgovine na daljavo, je sezonska trgovina. Dodatne vire dohodka so služili kot potujoči trgovci oz. kot t. i. "guziranci« (kramarji), ki so v srednji in vzhodni Evropi prodajali okrasne predmete avstrijskih podjetij ter izdelke podjetja Remondini iz mesta Bassano del Grappa. Izseljevanje je bilo sezonskega značaja in je potekalo od jeseni do začetka pomladi, kar je bilo vezano na manjšo intenzivnost kmetijskih opravil. Sčasoma je sezonska prodaja izdelkov med prebivalci dolin postala tako razširjena, da je družina Remondini v Špetru leta 1766 odprla svojo podružnico, preko katere so kramarji naročali in prejemali blago. Pred tem so naročeno blago dobavljali v Vidmu. Poleg Remondinijev se med dobavitelji blaga nadiškim kramarjem omenjajo tudi habsburški trgovci. Glavne smeri prodaje blaga nadiških kramarjev so bile v prvi polovici 19. stoletja tri. Prva je vodila preko Avstrije do Moravske, druga je potekala ob reki Savi čez (današnje države) Slovenijo, Hrvaško, Srbijo, Bosno do Banata v Romuniji, tretja pa je sledila poti proti Madžarski in v smeri Ukrajine (Zanini 2009). Med blagom, ki so ga guziranci prodajali na tujem, lahko naštejemo različne vrste tiskovin, ${ }^{\text {Is }}$ knjige, »svetnike, podobice in druge podobne predmete, « sicer poredko pa se med prodajnim blagom pojavljajo celo zdravila.

Posledice razmaha sezonske trgovine v Nadiških dolinah so bile za prebivalce tako pozitivne kot negativne. Kramarji so likviden denar za nakup trgovskega blaga največkrat pridobili tako, da so zastavili svoje premoženje oz. nepremičnino, ki naj bi jo ob prihodu domov ponovno odkupili. $\mathrm{V}$ ta namen so $\mathrm{z}$ agenti podjetja Remondini ali drugimi posamezniki sklenili pogodbe tipa pensione livellaria francabile, o katerih bo več povedanega v nadaljevanju. Drugi način, s katerim so si priskrbeli blago za nadaljnjo prodajo, je bilo sklepanje poroštev (pieggio). Le redki so s trgovino uspeli zaslužiti dovolj dobro, da so lahko svoje zemljišče odkupili oz. dobiček investirali v nov nakup. Včasih so tudi sami nastopali kot posojilodajalci in so s posamezniki sklepali pogodbe pensione livellaria francabile ter si tako zagotavljali rento. Bistveno več je bilo tistih, ki so se bili ob vrnitvi domov primorani še dodatno zadolžiti ali pa so bili izterjani za dolgove $\mathrm{z}$ rubežem oz. so za njihove dolgove morali odgovarjati poroki. Tudi

15 ASU, ANA, šk. 4434, not. reg. I, 262v-263r; 27or; šk. 1466, not. reg. za leta 1767-1769, 25r. O vrstah tiskovin in vzorcih podjetja Remondini glej Milano in Giacomello 2009, 107-236. 
življenje kramarjev v tujini ni bilo lahko, veliko jih je umrlo zaradi bolezni ali pa so postali žrtve ropov in napadov oz. nesreč ali »svojega lastnega obupa« (Zanini 2009, 73). S sezonsko trgovino so Nadiške doline postale trgovinsko bolj odprte ne samo bližnjim furlanskim trgom ter slovenskim deželam, ampak tudi širše, proti vzhodni Evropi.

Naštete in opisane neagrarne dejavnosti, ki so se jih posluževali kmetje v Nadiških dolinah, izkazujejo njihovo precejšnjo raznovrstnost. Gre za dejavnosti, ki jih srečamo tudi v slovenskih deželah in nasploh širše $\mathrm{v}$ vzhodnem predalpskem prostoru (Panjek 2014; 2015). Zasledimo pa v Nadiških dolinah tudi druge, ne toliko tipične načine pridobivanja dodatnih virov dohodka, ki so se jih posluževale vaške skupnosti kot celota in ne posamezniki znotraj njih. Njihov glavni namen je bil, da določen delež denarja pridobijo iz neagrarnih dejavnosti za poplačilo obveznosti ali za poravnavo raznih skupnih stroškov.

Eden takih je primer upravljanja $\mathrm{z}$ gozdnim zemljiščem, ki ga je $\mathrm{v} 17$. stoletju skupnost Arbeča podelila v koncesijo Valentinu Muschioneju iz Rubignacca za sečnjo lesa $v$ gozdu, iz katerega bi izdeloval apno za gradnjo utrdbe v Palmi. ${ }^{16}$ Muschione je moral skupnosti oz. njenemu notarju s pisnim dokazilom oblasti v Palmi dokazati, da bo gozd res izkoriščal za potrebe gradnje utrdbe. Skupnost mu je nato dodelila bukov gozd za obdobje osmih let $v$ višini 100 dukatov. Tega zneska pa Muschione ni izplačal neposredno skupnosti, temveč Giacintu Palinu iz Čedada, in sicer skupaj z zakupnino (affitto), obenem pa je moral od g. Palina pridobiti »osvoboditev« (francazione) v korist članov skupnosti za omenjen kapital. To verjetno pomeni, da je imela skupnost s Palinom sklenjen livello francabile za gozd, zdaj pa so izkoristili priložnost, da so se (vsaj delno) osvobodili plačevanja zakupnine. Tako je Muschioni z izplačilom zneska od oddaje gozda osvobodil skupnost od prejšnje pogodbe, poleg tega pa je moral dati še vsakemu članku skupnosti po en kvinč vina in hlebec kruha. Če se navedenih zahtev ne bi držal, bi bila pogodba šteta za nično. Dani primer pokaže, kako je skupnost pridobivala denar od enega in istega gozda s sklepanjem kreditnih pogodb oz. oddajo v zakup in si tako zagotavljala dodaten vir dohodka. Tovrstno upravljanje s srenjskimi gozdovi je znana praksa $\mathrm{v}$ sosednji beneški Karniji (Bianco 2001; Bianco 2003b, 34-5).

Drugi primer pridobivanja denarnih virov dohodka je podelitev peke kruha v affitto semplice krčmarici Ivani Šavli. Leta 1779 so na sosednji v Barnasu izbrali dva odposlanca, ki bosta predstavljala skupnost pred

16 ASV, ANA, šk. 4405, dok. št. 152. 
oblastmi v sporu z enim od članov skupnosti. Ta naj bi povzročil »izgubo« s prodajo kruha in s tem prizadejal škodo dacu od prodaje le-tega. Obenem so na skupščini izglasovali, da peko kruha podelijo "zanesljivi in odgovorni« krčmarici Ivani Šavli, vendar pod pogojem, da bo ta predala v podnajem del omenjenega daca »osebam, živečim v (tej) vasi, in sicer za morebitne potrebe in udobnost prebivalcev (te) vasi ter vernikov, ki prihajajo obiskat svetišče (te) častitljive cerkve Svete device Marije «. ${ }^{17} \mathrm{Na}$ ta način so si vaščani zagotovili dohodek od obresti, ki so jih prejemali od kratkoročnega zakupa, ter si hkrati pridržali možnost peke kruha za prodajo romarjem, s čimer so lahko dopolnjevali dohodke svojih gospodinjstev.

Posebej zanimiv primer integrirane kmečke ekonomije in podjetnosti je gostilna $\mathrm{v}$ Ažli, ki jo je skupnost zgradila $\mathrm{z}$ namenom, da s ponujanjem nastanitev in prodajo presežkov vina, pridelanega v skupnosti, pridobi dodatne vire dohodka.

\section{Gostišče vaške skupnosti v Ažli}

O tem, da bi zgradili stavbo, v kateri bi delovalo gostišče, so člani vaške skupnosti Ažla razmišljali vsaj že od leta 1768. Razprave in končne sklepe so vaščani obravnavali na sosednjah oz. vaških skupščinah, povzetek obravnav pa je v svoje knjige registriral notar Lovrenc Kukovac iz Špetra. Njegovi zapisi so glavni vir za rekonstrukcijo zgodbe o nastanku gostišča.

Na skupščini dne 3. februarja 1768, ki so jo sklicali »na običajnem mestu, z udarjanjem na zvon«, so prisotni župan, zapriseženec, vaški glavarji in drugi vaščani razpravljali o izgradnji hiše "na mestu, imenovanem pri kamnitem mostu sv. Kvirina«. Hiša bi služila kot krčma v skupno »korist, uporabo in udobje popotnikom in tujcem, tako beneškim kot cesarskim, na stroške vaške skupnosti ${ }^{18}{ }^{18}$ Zemljišče, na katerem so želeli zgraditi stavbo, je bilo državno, v lasti »našega presvetlega princa«, zato so člani skupnosti svoja sovaščana Antona Tropino in Mihaela Vinturina imenovali za odposlanca, ki bi v imenu skupnosti pristojne zaprosila za vsa dovoljenja in licence za izgradnjo stavbe na državnem zemljišču. Glasovanje je potekalo s kroglicami, in sicer je bilo 57 prisotnih za, proti pa le 1, in to župan.

Kot kaže, takratna ideja skupnosti Ažla ni zaživela, saj so na skupščini avgusta leta 1780 (znova) razpravljali o izgradnji gostilne, pri čemer so izhajali iz ugotovitve o tem, da »skoraj vsako leto in še posebej v obilnih leti- 
nah « njihovo vino ostaja »neprodano, v hudo škodo članov vaške skupnosti «. ${ }^{19}$ Po zgledu »raznih drugih vaških skupnosti« so ponovno ugotovili, da bi bilo potrebno postaviti »manjšo zgradbo, ki bi se uporabljala za gostilno na primernem kraju, $v$ kateri bodo lahko člani skupnosti poskrbeli za prodajo svojega vina«. Soglasni so bili v mnenju, da bi bil najprimernejši kraj za njeno postavitev na stičišču dveh glavnih cest, ki peljeta proti Špetru oz. Svetem Lenartu. Za dovoljenje za izgradnjo so morali zaprositi Urad za državna srenjska zemljišča, saj je bilo zemljišče, na katerem bi postavili zgradbo, v lasti države in je že bilo "podeljeno [v uporabo] tej vaški skupnosti, kot izhaja iz njene investiture «, vendar je bilo slabo rodovitno in $\mathrm{v}$ nobeno korist. ${ }^{20} \mathrm{~V}$ ta namen so zopet glasovali s kroglicami in za svojega prokuratorja izvolili gospoda Bernardina Torona, posrednika v Benetkah, ki naj bi pred Uradom za državna srenjska zemljišča predstavil njihovo željo in v njihovem imenu zaprosil za dovoljenje, da zasedejo omenjeno srenjsko zemljišče ter na njem sezidajo poslopje.

Urad je omenjeno zemljišče skupnosti prodal po pogodbi $\mathrm{z}$ dne 6 . septembra 1780 . Cena je znašala 450 malih lir oz. 150 dukatov (po 6,2 liri za dukat) za (veliki furlanski) čamp. ${ }^{21}$ Po tem nakupu se je 25 . septembra 1780 skupnost znova zbrala, da bi razpravljala o nadaljnji gradnji gostišča. Notarski zapis tokrat razkriva več podrobnosti o samem gostišču in njegovi postavitvi, kompleksnemu načinu financiranja ter posredno tudi o načinu delovanja vaške skupnosti. ${ }^{22}$

Kot je že bilo omenjeno, je skupnost od beneške države odkupila del srenjskega zemljišča v velikosti 600 tavol ob mostu pri sv. Kvirinu. Kot raz$\log$ za postavitev gostišča so navedli, da bi ta služil za lagodje in nastanitev tujcev ter prebivalcev Nadiških dolin, ki prečkajo doline s svojimi vozovi in so namenjeni v Čedad, Videm, Palmo ter druge vasi v Furlaniji "prodajat mlečne izdelke, sadje in druge proizvode 'Sklavonije' ter po drugih nujnih opravkih«, hkrati pa želijo pridobiti »kakšen dobiček od najema te stavbe, s katerim bi bilo manj težko prenesti vsakoletna bremena in davščine, ki jim je podvržena ta vaška skupnost«.

Ker pa vaška skupnost ni imela denarja, s katerim bi zgradila želeno gostišče, so se na skupščini dogovorili, da zanj zaprosijo brata Dominika in

\footnotetext{
19 ASU, ANA, šk. 4437, not. reg. S, 2107v.

20 ASU, ANA, šk. 4437, not. reg. S, 2108r.

21 ASU, ANA, šk. 4437, not. reg. T, 2275 r.

22 Celoten notarski zapis, po katerem tu povzemamo in citiramo, je v ASU, ANA, šk. 4437 , not. reg. S, 2124V-2126v.
} 
Matijo Mulloni iz skupnosti Šenčur. Predlagali so jima zapleten način financiranja, po katerem bi ob koncu gradnje od nje ter od oddaje gostilne imeli finančne koristi obe strani. Postavke so bile sledeče:

1. Po prvi postavki sta se brata Mulloni zavezala, da bosta prispevala, torej skupnosti oz. njenim predstavnikom izplačala ves potreben denar za izgradnjo gostišča. Ta naj bi imel v pritličnih prostorih »kuhinjo, peč in klet ter ognjišče z napo, dimniško cevjo ter dimnikom, zgrajenim zunaj kuhinje«, tri sobe zgoraj ter svoje skladišče za žito. Ta del bi bil pokrit s korci, posebej pa bi imela še hlev za živino. Brata sta se še zavezala, da bosta sproti in pravočasno izplačevala denar skupnosti, ki ga bo ta potrebovala med gradnjo za plačila mojstrom, zidarjem, delavcem, kamnosekom ter za nakup materiala, kot so železo oz. železarski izdelki, apno, tlakovci, korci idr., obenem pa bosta prevzela odgovornost za morebitne dodatne stroške, ki bi nastali zaradi nerednih izplačil.

2. Člani skupnosti so se v drugi postavki zavezali, da bodo na lastne stroške prepeljali dovolj zemlje, s katero bodo uredili vrt in obdali celotno zemljišče gostilne $\mathrm{v}$ obsegu 600 tavol ter na njem $\mathrm{v}$ naslednjih letih posadili ustrezno število kakovostnih murv.

3. Po tretji postavki bo skupnost bratoma Mulloni stavbo oz. gostišče, ki ga je potrebno še zgraditi, in pripadajoče zemljišče (6oo tavol) z vsemi murvami, ki bodo zasajene na njem, ter vrtom podelila $\mathrm{v}$ zakup $\mathrm{v}$ obliki affito semplice za obdobje pet let, $\mathrm{z}$ možnostjo obnovitve za nadaljnjih pet let.

4. Skupnost bo tu nastopala kot najemodajalec, brata pa kot najemnika. Dogovorjena letna zakupnina bo znašala 300 lir.

5. Nepravično in nekoristno « pa bi bilo, če bi vloženi denar, ki ga bosta posodila brata za izgradnjo gostišča, ostal »neploden «, zato sta se pogodbeni stranki v peti postavki dogovorili, da bo skupnost Mullonijema plačala $5 \%$ obresti na vse zneske, ki jih bodo ti potrošili za financiranje gradnje. Mullonija bosta morala $\mathrm{v}$ ta namen imeti točne izkaze za vsak strošek posebej, po katerih bodo lahko določili pravi končni znesek, ki ga bosta posodila za gradnjo. Stranki sta se tudi dogovorili, da se bo skupnost lahko osvobodila (affrancarsi) plačevanja obresti z izplačilom kapitala oz. končnega zneska (glavnice posojila), in sicer ali v celoti ali pa po letnih obrokih v višini 50 dukatov. V slednjem primeru se bo glavnica sproti ustrezno zmanjševala. 
6. V Šesti postavki so se dogovorili, da bosta morala brata Mulloni pravočasno plačevati znesek 300 lir za affito semplice ali pa ga delno ali v celoti pobotati $\mathrm{z}$ obrestmi, ki jih bo prinesel prej (v peti postavki) omenjeni livello v njuno korist. Če bosta brata plačevala redno znesek zakupnine (in sicer v gotovini ali delno kompenzacijo $\mathrm{z}$ obrestmi od posojila), jima skupnost ne bo smela odpovedati najema oz. ju »odsaditi« (escomio), dokler jima ne bo povrnila celotnega zneska posojila s pripadajočimi obrestmi. Brata pa bosta lahko ob vsakemu izteku petletne zakupne pogodbe za gostilno prekinila najem po svoji presoji, ne glede na to, ali je bil dotlej navedeni livello »osvobojen «, torej so bili glavnica in obresti v celoti izplačani, ali ne.

7. V zadnji postavki sta se stranki še dogovorili, da bosta določili tako datum nastopa v veljavo omenjenega affitta semplice v višini 300 lir za najem gostišča kot tudi datum, od katerega se bodo pričele zaračunavati obresti od livella za posojila $\mathrm{v}$ namen gradnje. Ta datuma bodo določili glede na hitrost napredovanja gradbenih del, zadovoljstvo obeh strani ter likvidnostni potreb bratov Mulloni.

Da bi gradnja stala čim manj in da bi bil s tem tudi omenjeni livello čim manjši, so se člani skupnosti na isti skupščini med seboj dogovorili in izglasovali, da bodo tisti, ki razpolagajo z vozom oz. s plino in z živino, prispevali h gradnji tako, da bodo vozili kamenje in pesek na gradbišče, in sicer proti plačilu »samo« 10 soldov za voz. Pri tem jim bodo morali drugi vaščani pomagati pri nalaganju materiala, sicer bodo kaznovani z globo $\mathrm{v}$ višini 4 lir v korist gastalda bank Landarja in Merse. Prav tako so bili tisti, ki imajo pline, obvezani prevažati material iz peči, kar zadeva prevoz lesa, pa bi bili prevozniki za to delo plačani v celoti.

Tisti člani skupnosti, ki niso posedovali voza, so se obvezali, da bodo pri gradnji pomagali kot fizični delavci zastonj in kot jim bo naročeno, sicer bodo vsakič kaznovani z globo 1 lire in 10 soldov.

$\mathrm{Na}$ koncu so se člani vaške skupnosti še dogovorili, da se bodo sovaščani, ki niso bili prisotni na skupščini in se ne bodo strinjali s temi odločitvami, morali vključno s svojimi dediči za vselej odpovedati vsem prihodkom in stroškom, ki bodo nastali z omenjenim gostiščem, vrtom in murvami ter s sklenjenim livellom.

Vaška skupnost je torej za izgradnjo gostišča sklenila dve pogodbeni razmerji z zasebnikoma, s katerima si je zagotovila potreben kapital za na- 
kup gradbenega materiala in poplačilo delavcev. Poglejmo si podrobneje ti dve pogodbeni razmerji.

Prvo, ki ga omenjajo v obravnavanem dokumentu, je affito semplice. $\mathrm{V}$ splošnem gre za kratkoročni zakup, $\mathrm{v}$ katerem se je kmet zavezal, da bo za določeno obdobje (običajno do pet let) vsako leto plačeval fiksne dajatve. Tovrstne kratkoročne zakupne pogodbe zasledimo $\mathrm{v}$ italijanskem prostoru od 15. stoletja dalje, ko se je pričela pojavljati tendenca zemljiških gospodov po uvajanju modernejših načinov obdelovanja zemljišč ter organizacije dela $\mathrm{z}$ namenom, da bi si zagotovili višje dohodke. Takšne pogodbe so namreč od zakupnikov predvidevale sajenje novih kulturnih rastlin, izboljšavo zemljišč ter obnovo poslopij, do česar kmet po dolgoročnem zakupu ni bil obvezan. $\mathrm{V}$ nasprotju $\mathrm{z}$ dolgoročnim zakupom takšna pogodbena razmerja kmetom ter njihovim družinam tudi niso zagotavljala stalnosti in samozadostnosti, saj so se običajno sklepala za posamezna zemljišča, zato so bili kmetje primorani vzeti v zakup po več zemljišč, ki so jih imeli v različnih zakupnih razmerjih. Kot druge oblike kratkoročnih razmerij lahko naštejemo še deležna razmerja (na primer spolovinarstvo, mezzadria) in mešane zakupe (na primer affitto misto) (Giorgetti 1974; Bianco 2011, 70-1).

Podobno stvarnost zasledimo tudi pri eni od obravnavanih hub $\mathrm{v}$ Gorenjem Barnasu, kjer najdemo sicer edini tovrstni primer affitta semplice na vseh trinajstih hubah. Na hubi Simona Zurata se sklenitev tega zakupnega razmerja prvič omenja leta 1644. Samostan je namreč v 17. stoletju polovico hube po sodni poti odkupil od soposestnikov, s čimer so slednji izgubili dedne pravice na tem delu hube. Na novo pridobljeni delež hube je nato samostan ponovno podelil drugemu zakupniku, tokrat $v$ kratkoročen zakup, in zanj predvidel vrsto novih dajatev, ki so bile izključno v naravi. Te so bile po sestavi raznovrstnejše in bi glede na svojo tržno vrednost za fevdalca predstavljale večji dohodek kot dajatve po dolgoročnem zakupu.

Affitto semplice pa se v Nadiških dolinah ne pojavlja samo v primeru zakupov zemljišč - poleg Gorenjega Barnasa jih zasledimo tudi v drugih vaseh -, temveč se tovrstno pogodbeno razmerje uporablja tudi v drugih primerih, kot je že omenjen zakup pravice za peko kruha krčmarici Ivani Šavli, in za oddajo v zakup tu obravnavane gostilne v Ažli. Pri slednji gre prav tako za kratkoročni zakup, ki ga stranki skleneta za petletno obdobje, z možnostjo podaljšanja za naslednjih pet let. Dajatev je fiksna in izključno v denarju, saj je prihodek od zakupljene stavbe $\mathrm{z}$ vrtom odvisen od denarnega zaslužka od oddaje prenočišč in prodaje vina. V primeru, da brata ne bi redno plačevala zakupnine, bi jima skupnost lahko zakup od- 
povedala. ${ }^{23}$ Izpostaviti velja kreativno uporabo pogodbene oblike, značilne za agrarna razmerja, $\mathrm{v}$ namene povsem drugačnih dejavnosti, kot sta peka kruha in najem gostišča.

Drugo pogodbeno razmerje, ki so se ga poslužili brata Mulloni in vaška skupnost, je pogodba, ki se v zapisu skupščine omenja kot livello. S tem terminom so $\mathrm{v}$ Beneški republiki označevali pogodbe različnih oblik, v Nadiških dolinah in tudi Karniji pa se je v glavnem nanašal na pogodbe, ki so bile namenjene kreditiranju in zavarovanju terjatev. Institut livello francabile (affrancazione pomeni osvoboditev, oprostitev) je bil sestavljen iz prodaje (običajno) nepremičnine in posoje denarja, čeprav le posredno. $Z$ vidika zakonitosti in formalnosti so se temu namreč želeli izogniti, saj je Cerkev obsojala posojanje za obresti. Zato pri pogodbah naletimo na precej kompleksno in zapleteno vsebino. Posojilojemalec oz. prodajalec je za vsoto, določeno $\mathrm{v}$ naprej in izplačano $\mathrm{v}$ denarju, prodal imetje posojilodajalcu oz. kupcu. To imetje je običajno predstavljala nepremičnina, v redkih primerih pa tudi premičnina. Kupec je isto nepremičnino istočasno podelil $\mathrm{v}$ zakup posojilojemalcu, od katerega jo je ravno pridobil, za dogovorjeno letno plačilo zakupnine, ki je predstavljala obresti. Po dogovorjenem obdobju je bil posojilojemalec upravičen lastnino ponovno pridobiti nazaj po enakem znesku, kot jo je zastavil (Corazzol 1979, 15-6; Fornasin 1998, 64; Monte 2000, 258).

$\mathrm{V}$ Nadiških dolinah tovrstne institute najdemo pod nazivoma livello francabile in pensione livellaria francabile. ॥V ekonomskem smislu je bila vsebina obeh pogodb enaka, saj sta obe vrsti pogodb posojilodajalcu omogočali kreditiranje, na podlagi katerega je prejemal obresti, posojilojemalec pa je pri tem za vračilo glavnice jamčil z nepremičnino. Vsebina teh pogodb je predvidevala zapis sklenitve razmerja med prodajalcem - posojilojemalcem (dolžnikom) in kupcem - posojilodajalcem (upnikom) za dogovorjeno vsoto. Ta je predstavljala glavnico, do izplačila katere se je za posojilo plačevala letna zakupnina oz. obresti, ki so po pogodbah znašale med 5 in $7 \%$. V obeh primerih se je posojilojemalec lahko 'osvobodil' plačevanja zakupnine oz. obresti tako, da je izplačal glavnico in s tem prekinil sklenjeno pogodbo«. Sklepanja pogodb tipa livello francabile so se na območju Nadiških dolin posluževale predvsem cerkve, s katerimi so upravljale vaške skupnosti, ter bratovščine. Pri tem so kot posrednika pri transakciji de-

23 Te pravice so se lastniki zemljišč običajno posluževali pri sklepanju začasnih zakupnih pogodb v primeru, ko je zakupnik kršil pogodbena načela oz. se jim izogibal, kot je na primer opravljanje izboljševalnih del na kmetiji ali polju (Bianco 2011, 71). 
narja vključevale posojilnico Monte di Pietà v Čedadu. Pogodbe tipa pensione livellaria francabile pa so pogosto sklepali potujoči trgovci »guziranci« s podjetjem Remondini za blago, ki so ga prodajali v tujino (Beguš 2015, 154-5, 170).

Vendar pa je med institutoma tudi razlika. Obresti so se pri institutu pensione livellaria francabile obračunale neposredno na posojen kapital, medtem ko so pri institutu livello francabile predstavljale letno zakupnino. Pri slednjem je namreč posojilojemalec prodal zemljišče za dogovorjeno vsoto in jo nato prejel nazaj v zakup ter v obliki zakupnine dejansko plačeval letne obresti. V primeru instituta pensione livellaria francabile pa je posojilojemalec tudi pravno gledano plačeval obresti na posojen kapital. V primeru instituta livello francabile je torej šlo za prikrito podeljevanje in prejemanje posojila, medtem ko je bila pensione livellaria odkrita oblika posojilne pogodbe, ki bi jo lahko primerjali z današnjim hipotekarnim kreditom.

V primeru obravnavane gostilne ugotovimo, da je pogodba, ki je bila sklenjena med upnikoma - Mullonijema in dolžnikom - vaško skupnostjo, tipa pensione livellaria francabile. Končni seštevek vseh stroškov v denarju je predstavljal glavnico, ki sta ga brata Mulloni vložila v izgradnjo gostilne. Skupnost se je pri tem zavezala, da bo plačevala $5 \%$ obresti na končni znesek, plačevanja teh obresti pa naj bi se osvobodila s poravnavo glavnice v celoti oz. po obrokih. Izplačilo glavnice je jamčila z nepremičnino s tem, ko se je v 6. členu pogodbe zavezala, da bratov ne bo »odsadila « $\mathrm{z}$ gostilne, preden ne poravna končnega zneska posojila (glavnice).

Leto kasneje, natančneje 2. oktobra 1781, je bilo gostišče že zgrajeno in dokončano. Brata sta $\mathrm{v}$ tem času spoštovala dogovor in prispevala ves denar, ki je bil potreben za izgradnjo gostišča ter poplačilo obrtnikov. Zato se je vaška skupnost odločila, da z njima sklene dogovorjen affitto semplice za obdobje in zakupnino, ki sta bila že dogovorjena poprej. Poleg tega so na tej skupščini obravnavali tudi skupni izračun nastalih stroškov gradnje, ki ga je pripravil javni izvedenec Karel Černoja. Ta je znašal 6.30o lir oz. 1.050 dukatov (po 6 lir za dukat). ${ }^{24}$

$\mathrm{K}$ notarskemu zapisu priložen popis stroškov izkazuje, da sta brata največ denarja izplačala za "razne« stroške, verjetno nastale predvsem za nakup materiala. Posebej so poplačali delo železarja, kamnoseka, tesarja ter zidarje. Slednji so bili poplačani za izgradnjo zidov gostišča, kritino, nanašanje malte ter izdelavo kamina, ki je obsegalo tlakovanje poda 
pod ognjiščem, izgradnjo peči, izdelavo nape, dimniške cevi in dimnika. Posebej so stroški nastali še za »lesene glave" pri kritini, štiri ogelnike, steklo za sedem letvanih oken $\mathrm{v}$ sobah zgoraj ter za štiri v kleti in sobi s pečjo spodaj, za dve okenski mreži v kleti ter mrežo ob ognjišču. Nekaj denarja so izplačali tudi trem prevoznikom (tabela 8.3).

Tabela 8.3: Stroški izgradnje gostišča

\begin{tabular}{|c|c|c|c|}
\hline Vrsta stroška & Lire & & Lire \\
\hline Začetni stroški & & & 1130,375 \\
\hline Razni stroški (nedefinirani) & & & 3492,35 \\
\hline Mojster obdelovalec železa & & & 114,00 \\
\hline Mojster kamnosek & & & 200,00 \\
\hline Mojster tesar & & & 259,9 \\
\hline \multirow[t]{6}{*}{$\begin{array}{l}\text { Mojstri za izdelavo zidu, kritine in } \\
\text { kamina }\end{array}$} & & za izgradnjo zidov & 494,75 \\
\hline & & za kritino & 223,1 \\
\hline & & $\begin{array}{l}\text { za izdelavo peči, kamina, tlaka } \\
\text { pod kaminom, nape, dimniške } \\
\text { cevi, dimnika, malte v sobi in } \\
\text { spalnici zgoraj }\end{array}$ & 90,00 \\
\hline & & za izdelavo lesenih glav pri kritini & 12,00 \\
\hline & & za 4 vogelnike & 44,00 \\
\hline & & $\begin{array}{l}\text { dodatek k plačilu za storjene } \\
\text { storitve }\end{array}$ & 22,00 \\
\hline 7 letvanih oken v zgornjem nadstropju & 84,00 & & \\
\hline $\begin{array}{l}4 \text { letvana okna in mreža v spodnjem } \\
\text { nadstropju, kjer sta peč in klet }\end{array}$ & 32,00 & & \\
\hline 2 mreži za balkon v kleti & 7,00 & & \\
\hline 2 mrežni rešetki za kamin & 12,00 & & \\
\hline $\begin{array}{l}\text { Delno so bili ti stroški že šteti v »razne } \\
\text { stroške» }\end{array}$ & $-48,1$ & & \\
\hline Od tega ostane še & 84,9 & & 84,9 \\
\hline poplačilo 3 prevoznikov & & & 3,5 \\
\hline$»$ Temu se doda še ...« & & & 129,125 \\
\hline Skupni seštevek & & & 6300 \\
\hline
\end{tabular}

Vir: ASU, ANA, šk. 4437, reg. T, 2275v-2276r.

Obe strani, tako brata kot prisotna skupnost, so izračun »popolnoma potrdili in odobrili«, kar je bil pogoj za sklenitev še drugega pogodbenega razmerja pensione livellaria francabile. Čeprav je bil dogovor, da se institut sklene za 5-odstotno letno obrestno mero, sta brata odločila, da obrestno mero znižata na $4 \%$. Na ta način sta želela nagraditi skupnost za trud in 
»velik napor, ki so ga člani vložili brez kakršnegakoli plačila [za delo] v novogradnjo «. Tako je vseh 51 poimensko zapisanih in tudi prisotnih članov vaške skupnosti Ažla $\mathrm{z}$ bratoma Mulloni sklenilo institut pensione livellaria francabile za glavnico v višini 1.050 dukatov po 4-odstotni obrestni meri, ki je na leto znašala 42 dukatov. Obresti so bili po pogodbi obvezani izplačevati »leto za letom « do »osvoboditve« s poravnavo glavnice v celoti ali po obrokih v višini 50 dukatov. Skupnost je za poravnavo glavnice jamčila skupno (ippotecano in solidum) z zemljiščem v obsegu 600 tavol, ki ga je odkupila od Urada za državna srenjska zemljišča in je z njim lahko trgovala, gostiščem in vrtom.

S plačilom obresti po pogodbi pensione livellaria francabile je skupnost pričela na dan 11. novembra "naslednjega leta«, istega dne in istega leta pa je "pričel teči« tudi affitto semplice za naslednjih pet let za najem gostišča. Gostišče v lasti vaške skupnosti Ažla je tako dobro leto po svoji izgradnji pričelo obratovati.

Enotna odločitev vaške skupnosti, da zgradi gostišče, tehtni razlogi za njegovo postavitev ter iznajdljiv način financiranja izkazujejo ekonomsko udejstvovanje te skupnosti v gostinski dejavnosti in dokazujejo, da se je ta zavedala možnosti dodatnega zaslužka v tej neagrarni panogi. Skrbno izbrana lokacija postavitve objekta ob stičišču dveh glavnih cest, po katerih so potovali domačini in tujci, potrjuje zavestno in racionalno izbiro ugodne prometne lokacije tako za vključevanje $\mathrm{v}$ trgovsko dejavnost s prodajo svojih (pol)izdelkov kot $\mathrm{z}$ nudenjem storitev $\mathrm{v}$ trgovini in prometu (prehrane, prenočitve, hleva za tovorno in vlečno živino, verjetno krme). $Z$ izgradnjo gostišča so domačini prispevali tudi $\mathrm{k}$ udobnejši in privlačnejši trgovski poti skozi doline, ki je že od 16. stoletja beležila upad prometa.

Poleg tega je samo gradnjo oz. gostinsko dejavnost podprla tudi država s tem, ko je skupnosti prodala zemljišče. Republika je tudi sicer, že od priključitve čedajskega območja in z njim Nadiških dolin v 15. stoletju, potrjevala in podeljevala določene privilegije, s katerimi je prebivalce dolin oproščala plačevanja davkov in jim $s$ tem omogočala vključevanje $v$ neagrarne dejavnosti. Ti privilegiji so namreč zadevali tista področja, ki so prebivalcem Nadiških dolin predstavljala pomemben vir dohodka. Med njimi omenimo oprostitev od plačevanja mitnin na prehod živine skozi mesto Čedad, plačevanja daca na meso, daca na mletje, daca na uvoženo vino ter davka na prodan kruh idr. (Beguš 2015, 79-85). Beneška republika se je torej zavedala, da se kmetje v Nadiških dolinah v svojem lokalnem okolju poslužujejo neagrarnih dejavnosti. To pa ne pomeni, da država ni 
skušala imeti nadzora nad gospodarskimi dejavnosti na svojem teritoriju, ravno obratno. $Z$ uvajanjem monopolov, na primer na prodajo toba$\mathrm{ka}$, organiziranjem policijskih enot ter s postavljanjem strogih kazni je Beneška republika skušala omejiti oz. odpraviti ilegalno trgovino, ki je bila v Furlaniji in gorskih območjih nasploh precej razmahnjena (Berengo 1956, 121-6; Bianco 1990). V primeru Nadiških dolin so bili davčni privilegiji omejeni pretežno na lokalno ekonomijo. Za prebivalce dolin so bile torej te posebne pravice in tudi samoupravne pristojnosti izrednega pomena, Republika pa si je na ta način pridobila njihovo brezpogojno lojalnost in varovanje mejnega območja s habsburškimi deželami.

Drugi ekonomski vidik, ki ga izkazuje primer iz Ažle, je iznajdljiva in kompleksna oblika financiranja gradnje gostišča. Člani skupnosti so poiskali domiselno rešitev za pridobitev denarnih sredstev s sklenitvijo dveh pogodb med skupnostjo in zasebniki in s tem uspeli uresničiti svoj načrt. Pri tem so pokazali sposobnost posluževanja pogodbenih razmerij, ki so bila sicer na območju Nadiških dolin in v Furlaniji precej razširjena. Enako lahko trdimo tudi za primera podelitve koncesije za upravljanje $\mathrm{z}$ gozdnim zemljiščem ter podelitve peke kruha $\mathrm{v}$ kratkoročni zakup krčmarici.

V splošnem gre za agrarne in kreditne pogodbe, ki so se jih v beneškem prostoru in tudi prebivalci dolin pretežno posluževali za zakup kmetijskih zemljišč oz. za izposojo denarja. V primeru gostišča pa je bil namen sklenitve pogodb drugačen, čeprav sta po formulaciji predvidevali sestavne dele, kot so jih običajno vsebovale tovrstne agrarne pogodbe. Uporaba pogodb affitto semplice in pensione livellaria francabile za namene najema gostišča in financiranja gradnje nepremičnine ni običajna. Instituti pensione livellaria francabile kot tudi livello francabile so po svoji vsebini predvidevali jamstvo posojilojemalca $\mathrm{z}$ nepremičnino do izplačila glavnice. Po teh pogodbah so torej nepremičnine predstavljale garancijo za posojen denar. V primeru gostišča $\mathrm{v}$ Ažli pa si je skupnost najprej morala zagotoviti denar za gradnjo gostilne, ki jo je šele po dovršeni izgradnji lahko zastavila kot jamstvo za poplačilo nastalih stroškov $\mathrm{z}$ obrestmi. Brez nepremičnine, ki bi jo zastavila, torej ne bi mogla pridobiti potrebnega kapitala za izvedbo svojega načrta. V primeru sklenjenega affitta semplice pa gre za to posebnost, da so tovrstno obliko pogodbe, ki je izvorno nastala in bila značilna za zakupe zemljišč v kmetijske namene, sklenili tudi za namene izvajanja neagrarne dejavnosti. Tako kažeta tako primer krčmarice Šavli, kjer je šlo za podelitev v zakup dejavnosti peke kruha, kot primer gostišča, kjer so v 
zakup dali nepremičnino, $\mathrm{v}$ kateri so izvajali gostinsko dejavnost. Kmetje iz Nadiških dolin so torej znali kreativno uporabiti pogodbena orodja, ki so jim bila znana iz agrarnega področja, $v$ namene povsem drugačnih dejavnosti. Tudi s tem so izkazovali svojo podjetnost.

\section{Zaključek}

$\mathrm{Na}$ osnovi navedenega lahko trdimo, da tudi v Nadiških dolinah prebivalci niso živeli ali mogli preživeti izključno od kmetijstva. To nam potrjuje tudi širok nabor neagrarnih dejavnosti ter vzroki za njihovo posluževanje, izpričani v številnih virih in omembah takratnih sodobnikov. Kot razkrivajo zapisi, so se nadiški kmetje neagrarnih dejavnosti posluževali predvsem zaradi preživljanja in zadovoljevanja svojih potreb ter pridobivanja dobrin, ki jih sami niso uspeli pridelati (dovolj). Obmejna lega s habsburškimi deželami ter cestne povezave in trgovski tokovi, ki so doline povezovali s furlanskimi, habsburškimi in $\mathrm{z}$ istrskimi mesti, pa tudi naravni viri, pri čemer mislimo predvsem na gozdove in les, ki so nudili surovino za izdelavo (pol)izdelkov, so prebivalcem dolin nedvomno ponujali možnost dopolnilne zaposlitve in dostopa do dodatnih virov dohodka.

Dejavnosti, s katerimi je kmečko prebivalstvo v Nadiških dolinah širilo svoje vire dohodka in ga povečevalo, so sodile v vse tri ekonomske sektorje, primarnega, sekundarnega in terciarnega. Nenazadnje spada v terciarni sektor tudi gostinska dejavnost, ki so jo izvajali člani vaške skupnosti Ažla. Ta predstavlja zelo jasen prikaz integriranja kmetijskih in neagrarnih virov dohodka ter obenem izrazit primer prizadevnosti, podjetnosti, iznajdljivosti in iniciativnosti kmečkega prebivalstva v Nadiških dolinah. Tako $\mathrm{v}$ splošnem kot $\mathrm{s}$ tem specifičnim primerom stvarnost Nadiških dolin deluje skladno s konceptom integrirane kmečke ekonomije (Panjek 2017a).

$\mathrm{Z}$ zamislijo o postavitvi gostilne ter izvedbo njene gradnje in financiranja so člani vaške skupnosti Ažla pokazali sposobnost posluževanja pravnih institutov in pogodbenih razmerij kot tudi izrazito povezanost in kohezivnost $\mathrm{v}$ doseganju skupnega cilja.

\section{Merske in denarne enote}

1 lokalni čamp $=1$ mali furlanski čamp (campo friulano piccolo $)=4$ quarti $=840$ tavole

1 lokalni čamp $=0,350583$ ha 
1 veliki furlanski čamp (campo friulano grande) $=1250$ tavole

1 lira $=20$ soldov $=12$ dinaričev

\section{Viri in literatura}

Arhivski viri

ASU: Archivio di Stato di Udine

ANA: Archivio notarile antico

CRS: Congregazioni religiose soppresse

ASV: Archivio di Stato di Venezia

CA, AP: Catasto Austriaco, Atti preparatori

PsB: Provveditori sopra boschi

PsF: Provveditori sopra Feudi

PaS: Provveditori alla Sanità

Inquisitori di stato

\section{Literatura}

Beguš, I. 2015. Avtonomija in ekonomija Nadiških dolin v Beneški republiki. Koper: Univerzitetna založba Annales.

Berengo, M. 1956. La società veneta alla fine del Settecento: ricerche storiche. Firenze: G. C. Sansoni.

Bianco, F. 1990. Contadini, sbirri e contrabbandieri nel Friuli del Settecento (Valcellina e Valcovera). Pordenone: Biblioteca dell'immagine.

Bianco, F. 1998. »La frontiera come risorsa. Il contrabbando di tabacco nella repubblica di Venezia in età moderna." Histriae der Alpes 3: 213-25.

Bianco, F. 2001. Nel bosco. Comunità e risorse forestali nel Friuli in età moderna (secoli $X V-X X)$. Udine: Forum edizioni.

Bianco, F. 2003a. Riforme fiscali e sviluppo agricolo nel Friuli napoleonico. Francesco Rota pubblico perito e agrimensore con il coraggio della verita e nell'interesse della Nazione. Udine: Forum edizioni.

Bianco, F. 2003b. Forestali, mercanti di legname e boschi pubblici. Candido Morassi e i progetti di riforma boschiva nelle Alpi Carniche tra Settecento e Ottocento. Udine: Forum edizioni.

Bianco, F. 2011. Krvavi pust. Kmečki upori in plemiške fajde v Furlaniji med 15. in 16. stoletjem. Koper: Univerzitetna založba Annales. 
Bianco, F. 2012. „Economia e società rurale nella bassa pianura del Friuli occidentale in età moderna. Le rendite dell'abbazia di Sesto.« V L'abbazia di santa Maria di Sesto nell epoca moderna (secoli XV-XVIII), uredil A. Tilatti, 211-376. Pasian di Prato: Lithostampa.

Blaznik, P. 1973. Škofja Loka in loško gospostvo (973-1803). Škofja Loka: Muzejsko društvo.

Castellarin, B. 2001. Il contrabbando in Friuli durante il dominio della Serenissima con particolare riguardo alla bassa Friulana. Latisana: Edizioni la bassa.

Corazzol, G. 1979. Fitti e livelli a grano. Un aspetto del credito ruralen el Veneto del '50o. Milano: Franco Angeli.

Corbellini, R., L. Cerno in C. Sava. 1992. Il Friuli nel 1807: dipartimento di Passariano. Popolazione, risorse, lavoro, in una statistica napoleonica. Udine: Società Filologica Friulana.

Fornasin, A. 1998. Ambulanti, artigiani e mercanti. L'emigrazione dalla Carnia in età moderna. Verona: Ciere edizioni.

Gestrin, F. 1973. »Boj za podeželsko trgovino med mestom in vasjo od konca 15. do srede 17. stoletja.«Jugoslovenski istorijski časopis 12: 72-80.

Gestrin, F. 1991. Slovenske dežele in zgodnji kapitalizem. Ljubljana: Slovenska matica.

Giorgetti, G. 1974. Contadini e proprietari nell'Italia moderna: rapporti di produzione e contratti agrari dal secolo 16. a oggi. Torino: Einaudi.

Milano, A., in A. Giacomello. 2009. „Gli ambulanti delle Valli del Natiosne e la diffusione delle stampe Remondini. Ipotesi per un catalogo illustrato; Stampe in rame; Stampe in legno; Carte decorate." V Guziranje. Dal dalla Schiavonia veneta all'Ongheria con le stampe dei Remondini = Z Beneškega na Ogrsko s tiskovinami Remondini, 107-236. Stregna: Comunità montana del Torre, Natisone e Collio.

Monte, M. 200o. „Costo del denaro e tassi d'interesse nell'attività di credito dei Regolari nel Friuli veneziano nel XVII e XVIII secolo.« Ce fastù? 76 (2): $253-84$.

Panjek, A. 2002. Terra di confine: agricolture e traffici tra le Alpi e l'Adriatico: la contea di Gorizia nel Seicento. Mariano del Friuli (Go): Edizioni della Laguna.

Panjek, A. 2011. "Not Demesne but Money: Lord and Peasant Economies in Early Modern Western Slovenia«. Agricultural History Review 59 (2): 293-311. 
Panjek, A. 2014. »Integrirana ruralna ekonomija v zahodnem slovenskem prostoru v zgodnjem novem veku.« V Vizija raziskav slovenske gospodarske in družbene zgodovine, uredila D. Mihelič, 199-205. Ljubljana: Založba ZRC.

Panjek, A. 2015. »Integrated Peasant Economy in Early Modern Slovenia: The Institutional Framework and the Concept." Histoire des Alpes 20: 187-207.

Panjek, A. 2017a. »The Integrated Peasant Economy as a Concept in Progress.« $\mathrm{V}$ Integrated Peasant Economy in a Comparative Perspective: Alps, Scandinavia and Beyond, uredili A. Panjek, J. Larsson in L. Mocarelli, 1149. Koper: Založba Univerze na Primorskem.

Panjek, A. 2017b. »Intangible and Material Evidence on the Slovenian Peasant Economy: Custom and Land Market in the Karst Highland (17th-18th Centuries)."V Integrated Peasant Economy in a Comparative Perspective: Alps, Scandinavia and Beyond, uredili A. Panjek, J. Larsson in L. Mocarella, 229-57. Koper: Založba Univerze na Primorskem.

Šumrada, J. 1987. »O popravilu bovške ceste na prelomu iz 14. v 15. stoletje.« Zgodovinski časopis 41 (2): 313-19.

Tagliaferri, A. 1976. Relazioni dei rettori Veneti in Terraferma. V., Provveditori di Cividale del Friuli, Provveditori di Marano, vol. V. Milano: Giuffré editore.

Tagliaferri, A. 1989. "Merci e mercanti alla muda di Pulfero in età veneziana." Memorie storiche forogiuliesi 68: 59-65.

Verbič, M. 1974. »Gospodarski in socialni položaj tolminskega kmeta v začet$\mathrm{ku}$ 16. stoletja in upori tolminskih kmetov v letih 1513 do 1515."Zgodovinski časopis 28 (1): 3-44.

Zanini, A. 2009. „Proti Nemčiji in Ogrski. Sezonsko izseljevanje iz beneške Schiavonie.« Guziranje. Dal dalla Schiavonia veneta all'Ongheria con le stampe dei Remondini = Z Beneškega na Ogrsko s tiskovinami Remondini, 67-84. Stregna: Comunità montana del Torre, Natisone e Collio.

Žontar, J. 1956-57. »Nastanek, gospodarska in družbena problematika policijskih redov prve polovice 16. stoletja za dolnjeavstrijske dežele s posebnim ozirom na slovenske pokrajine.«Zgodovinski časopis 10-11: 32-121. 